\title{
Penentuan Kriteria dan Strategi dalam Menghadapi Peperangan Kepulauan dengan Pendekatan Dematel - ANP
}

\author{
Didit Herdiawan, Ahmadi, Haryanto Wibowo \\ Sekolah Tinggi Teknologi Angkatan Laut, Surabaya \\ dr_ahmadi@sttal.ac.id
}

DOI: https://doi.org/10.21107/rekayasa.v13i1.5872

\begin{abstract}
ABSTRAK
TNI Angkatan Laut merupakan salah satu komponen pertahan Negara di laut. Dihadapkan dengan dinamika lingkungan strategis maka TNI AL harus mampu untuk meningkatkan kemampuan pertahanan untuk dapat mengatasi ancaman peperangan permukaan, peperangan amfibi, peperangan khusus (anti nubika, anti teror dan lawan sabotase bawah air), serta kemampuan Anglamil (Angkutan Laut Militer). Melihat kondisi geografis Indonesia yang merupakan Negara Kepulauan dengan beraneka ragam konfigurasi geografi yang dimiliki, maka TNI AL dapat menjadikan kondisi geografis ini sebagai strategi dalam pertempuran yaitu Peperangan Kepulauan. Berdasarkan latarbelakang tersebut maka perlu adanya penentuan kriteria yang secara objektif dapat mempengaruhi dari model strategi TNI AL dalam usaha untuk memenangkan Peperangan Kepulauan. Sehingga diperoleh pilihan strategi yang tepat untuk melaksanakan Peperangan Kepulauan. Untuk membahas permasalahan tersebut digunakan pendekatan DEMATEL (Decision Making Trial and Evaluation Laboratory) untuk melihat hubungan keterkaitan antar kriteria dan subkriteria. Kriteria utama yang diperoleh adalah Konstelasi Geografi, Taktik Peperangan Kepulauan, Postur Kekuatan TNI AL, Kekuatan Negara Ancaman dan Peran Dawilhanla. Kemudian dilakukan perancangan model dalam pemilihan strategi Peperangan Kepulauan dengan pendekatan ANP (Analytic Network Process). Hasil dari pengolahan data yang dilakukan diperoleh bobot prioritas alternatif yang terpilih yaitu Decisive Battle $(0,06369)$, Blockade $(0,06120)$ dan Fleet in Being $(0,04800)$. Selain itu dilaksanakan analisis BOCR (Benefit, Opportunity, Cost and Risk) diperoleh hasil berdasarkan skenario standar Fleet in Being dengan bobot 0,56233, skenario pesimis terpilih alternatif Decisive Battle dengan bobot 0,09169 dan skenario realistis terpilih alternatif Decisive Battle dengan bobot 0,02237.

Kata Kunci: DEMATEL, ANP, Peperangan Kepulauan, Analisis BOCR (Benefit, Opportunity, Cost and Risk).
\end{abstract}

\section{PENDAHULUAN}

TNI Angkatan Laut merupakan salah satu komponen pertahanan negara di Laut (Marsetio, 2013). Dihadapkan dengan perkembangan lingkungan strategis Negara Kesatuan Republik Indonesia, kondisi postur TNI Angkatan Laut saat ini sangat penting. Hal ini sebagai perwujudan dari kemampuan TNI Angkatan Laut di dalam bidang pertahanan. Kemampuan pertahanan itu sendiri penggabungan dari profesionalisme prajurit dan kesiapan alutsista (Alat Utama Sistem Senjata) untuk melaksanakan kegiatan penegakan kedaulatan dalam rangka menjaga keutuhan wilayah NKRI (Purwoto, 2014). Kondisi kemampuan pertahanan yang perlu ditingkatkan antara lain kemampuan peperangan permukaan, kemampuan peperangan amfibi, kemampuan peperangan khusus (seperti kemampuan anti nubika, anti teror, dan lawan sabotase atas atau bawah air), serta kemampuan anglamil (Angkutan Laut Militer) di dalam mendukung serpas (Pergeseran Pasukan) dan serlog (Pergeseran Logistik) di dalam operasi laut.

\section{Article History:}

Received: August, 27 ${ }^{\text {th }}$ 2019; Accepted: January, $12^{\text {nd }} 2020$ ISSN: 2502-5325 (Online) Terakreditasi Peringkat 3 oleh Kementerian Riset, Teknologi dan Pendidikan Tinggi (ARJUNA), berdasarkan Keputusan Direktur Jenderal Penguatan Riset dan Pengembangan No: 23/E/KPT/2019 tanggal 8 Agustus 2019
Salah satu bentuk kemampuan tempur yang harus dimiliki oleh TNI Angkatan Laut adalah kemampuan di dalam peperangan kepulauan. Fakta yang ada bahwa negara Indonesia memiliki konfigurasi geografis yang sebagian besar wilayahnya terdiri dari lautan serta pulau-pulau besar dan kecil yang berjumlah 17.504 pulau (Pushidrosal, 2017). Menurut UNCLOS 1982 negara kepulauan berarti suatu negara yang seluruhnya terdiri dari satu atau lebih kepulauan dan dapat mencakup pulau-pulau lain. Kondisi ini apabila ditinjau dari geostrategi, geopolitik, dan geoekonomi memiliki peran yang penting bagi negara Indonesia (W.Wardhana, 2016), karena membutuhkan peran untuk mempertahankan serta mengatasi serangan dari luar melalui laut.

Bentuk geografis Indonesia yang berupa gugusan pulau (Lasabuda, 2013), memberikan karakter atau sifat tertentu pada masalah hidro-oseanografi. Banyaknya selat dan pulau antara, akan memberikan pengaruh terhadap aliran arus yang secara langsung dapat mempengaruhi parameter-

\section{Cite this as:}

Herdiawan, D. Ahmadi, A. Haryanto Wibowo, H. (2020).

Penentuan Kriteria dan Strategi dalam Menghadapi Peperangan Kepulauan dengan Pendekatan Dematel - ANP. Rekayasa, 13(1), 1-14. doi: https://doi.org/10.21107/rekayasa.v13i1.5872 (c) 2020 Didit Herdiawan, Ahmadi, Haryanto Wibowo 
parameter karakteristik air laut seperti salinitas, arus permukaan, arus pasang surut, dan arus pantai. Selain itu, karakteristik ruang atau dimensi udara di wilayah Indonesia sangat dipengaruhi oleh kondisi iklim laut sebagai akibat luas lautan yang lebih besar dibandingkan daratan yang tersusun dalam bentuk pulau-pulau.

Berdasarkan kondisi dan konstelasi geografis yang dimiliki oleh negara Indonesia, serta adanya pengaruh hidro-oseanografi maka TNI Angkatan Laut dapat memanfaatkannya di dalam sistem pertahanan negara. Bentuk fisik negara Indonesia sebagai negara kepulauan secara strategis, operasional, maupun taktis akan lebih menguntungkan di dalam pemanfaatannya yang diwujudkan di dalam strategi peperangan kepulauan. Peperangan kepulauan itu sendiri memiliki arti upaya mempertahankan kedaulatan wilayah yurisdiksi nasional Indonesia dengan kemampuan dan kekuatan TNI Angkatan Laut yang dimiliki serta mampu melaksanakan pengendalian laut melalui pemanfaatan kondisi dan konstelasi geografis Indonesia. Komponen-komponen yang memiliki dampak bagi penggunaan strategi peperangan kepulauan oleh TNI Angkatan Laut yaitu prediksi ancaman, konfigurasi geografi kepulauan, hidro-oseanografi, meteorologi, dan Postur TNI Angkatan Laut. Masing-masing komponen saling memiliki keterkaitan di dalam keberhasilan pelaksanaan strategi peperangan kepulauan. Penggunaan Alutsista dan pemanfaatan kondisi geografis serta ikut sertanya seluruh sumber daya pangkalan yang dimiliki di daerah perang sangat menentukan keberhasilan di dalam pertempuran.

Strategi peperangan kepulauan merupakan salah satu bagian dari Strategi Pertahanan Laut Nusantara (SPLN). Strategi Pertahanan Laut Nusantara mengacu kepada dinamika atau perkembangan lingkungan strategis dan kemampuan sumber daya nasional yang tersedia. Strategi-strategi yang digunakan di dalam pelaksanaan SPLN itu sendiri adalah strategi penangkalan, strategi pertahanan berlapis, dan strategi pengendalian laut. Sedangkan medan juang dari SPLN dibagi menjadi tiga wilayah, yaitu medan pertahanan penyanggah wilayahnya di luar garis batas ZEEI (Zona Ekonomi Eksklusif Indonesia), medan pertahanan utama meliputi laut teritorial sampai dengan ZEEI, serta daerah perlawanan yang di dalamnya terdapat laut teritorial dan perairan kepulauan. Penggunaan strategi peperangan kepulauan dilaksanakan di dalam wilayah medan pertahanan utama pada SPLN. Strategi yang mendukung di dalam pelaksanaan peperangan kepulauan yang dapat dilakukan yaitu strategi blokade, strategi Decisive Battle, dan Fleet in Being. Di mana masing-masing strategi di dalam peperangan kepulauan tersebut memiliki kelebihan dan kekurangan.

Beberapa penelitian yang dilakukan berkaitan dengan peperangan kepulauan yaitu sebuah kajian tentang peningkatan kewaspadaan bawah laut di wilayah perairan Swedia, observasi data melalui strategi yang digunakan yaitu Archipelagic Anti Submarine Warfare (Svensson, 1998). (Reeve, 2001) melakukan pengembangan konsep mempertahankan wilayah perairan kepulauan Australia. Sebuah kajian perencanaan strategi pengamanan Alur Laut Kepulauan Indonesia (ALKI) dengan pola choke point control menerapkan kemampuan pengawasan Kapal Republik Indonesia wilayah barat (Pranoto \& Octavian, 2015). Perencanaan pertahanan wilayah kepulauan juga dilakukan oleh negara Jepang dan Amerika (Andrew F. Krepinevich, 2017).

Selain itu terdapat beberapa penelitian yang berhubungan dengan strategi dan metode pendekatan yaitu penelitian tentang pemilihan strategi pemasaran Surabaya Plaza Hotel akibat dari meningkatnya persaingan di industri perhotelan dengan pendekatan DEMATEL, ANP, dan Zero-One Goal Programming (Puspitasari \& Ciptomulyono, 2011). Studi tentang penerapan metode DEMATEL dan ANP di dalam analisis perbandingan CB (Cara Bertindak) pada proses perencanaan operasi amfibi (Bintoro, 2013). (Sadehnezhad, Zaranejad, \& Gheitani, 2013) melakukan sebuah studi tentang evaluasi kinerja intelijen bisnis pada sebuah organisasi dengan menggabungkan metode DEMATEL dan ANP dengan pendekatan fuzzy. (Sari, Santoso, \& Hamdala, 2014) melakukan penelitian pengambilan keputusan strategi pemasaran PT $X$ di Mojokerto, melalui pendekatan menggunakan metode ANP dan Fuzzy TOPSIS. Sebuah penelitian tentang penentuan alokasi pesanan bahan baku pada PT. Djarum Kudus dengan pengintegrasian fuzzy TOPSIS dan Multi Choice Goal Programming (Sari, Pujotomo, \& Maryani, 2015).

Penelitian-penelitian yang telah dilaksanakan tersebut memiliki perbedaan baik dari objek yang diteliti ataupun dari pendekatan metode yang digunakan. Di dalam penelitian ini untuk mendapatkan pilihan strategi yang tepat oleh TNI AL dalam rangka Peperangan Kepulauan memerlukan kajian ilmiah terkait dengan kompleksitas faktor yang mempengaruhi kemenangan di dalam Peperangan Kepulauan. Terlebih lagi melihat kondisi geografi Indonesia sebagai Negara Kepulauan yang dapat dijadikan sebagai peluang untuk memenangkan pertempuran. Sehingga melalui penelitian dapat memberikan masukan ilmiah di dalam pengambilan keputusan untuk melakukan strategi di dalam 
Peperangan Kepulauan. Oleh karena itu melalui penelitian ini diharapkan dapat mengembangkan suatu model strategi yang dilakukan oleh TNI Angkatan Laut dalam menghadapi Peperangan Kepulauan. Salah satu pendekatan untuk menganalisis kompleksitas di dalam pengambilan keputusan strategi digunakan pengintegrasian pendekatan DEMATEL (Decision Making Trial and Evaluation Laboratory) dan ANP (Analytic Network Process). Melalui kriteria awal yang diperoleh dari narasumber atau expert, penulis berusaha untuk menentukan hubungan dan derajat perbedaan pengaruh antar kriteria dalam strategi peperangan kepulauan menggunakan metode DEMATEL (Decision Making Trial and Evaluation Laboratory). Hasil dari pengolahan data DEMATEL akan digunakan sebagai dasar dalam penentuan bobot kriteria untuk memilih alternatif strategi peperangan kepulauan dengan menggunakan ANP (Analytic Network Process). Kemudian hasil dari ANP memberikan solusi pilihan alternatif strategi terbaik TNI Angkatan Laut di dalam Peperangan Kepulauan. Melalui kajian ilmiah ini diharapkan TNI Angkatan Laut untuk menghadapi peperangan kepulauan dapat menggunakan alternatif strategi yang tepat serta alokasi sumber daya yang dimiliki dioptimalkan sebagai minimum requirements untuk mempertahankan wilayah kedaulatan Negara Republik Indonesia.

Adapun problem statement yang dapat diangkat dalam penelitian ini adalah "Bagaimana melakukan pemodelan strategi dan alokasi sumber daya TNI Angkatan Laut dalam usaha untuk menghadapi peperangan kepulauan. Selanjutnya akan dicari kriteria apa saja yang dapat mempengaruhi model strategi di dalam peperangan kepulauan serta Strategi apa yang paling tepat digunakan oleh TNI Angkatan Laut, dihadapkan dengan kondisi geografis negara Indonesia untuk menghadapi peperangan kepulauan termasuk kebutuhan alokasi sumber daya TNI Angkatan Laut di dalam menghadapi Peperangan Kepulauan.

\section{KAJIAN PUSTAKA}

\section{Penelitian Terdahulu}

Konsep mempertahankan wilayah perairan kepulauan juga dikembangkan oleh Royal Australian Navy (Reeve, 2001). Pada penelitian ini juga mengambil langkah strategi di dalam mempertahankan wilayah pesisir Australia. Peneliti melakukan kajian kualitatif berdasarkan data historis yang sudah terjadi pada saat perang dunia kedua dan perimeter-perimeter penyebab kegagalan Jepang di dalam merencanakan strategi sekitar wilayah kepulauannya.

Sebuah penelitian tentang perencanaan strategi juga dilakukan untuk memilih strategi pemasaran (Puspitasari \& Ciptomulyono, 2011). Peneliti melakukan penelitian tentang pemilihan strategi pemasaran Surabaya Plaza Hotel akibat dari meningkatnya persaingan di industri perhotelan. Di dalam merencanakan pemilihan strategi peneliti melakukan pendekatan menggunakan beberapa metode yaitu DEMATEL (Decision Making Trial and Evaluation Laboratory) untuk menganalisis antara kriteria terkait, metode ANP (Analytic Network Process) untuk menentukan bobot masing-masing alternatif, kemudian hasil ANP diintegrasikan sebagai parameter model ZOGP (Zero-One Goal Programming). Hasil dari ZOGP digunakan untuk mengoptimalkan alternatif strategi yang akan dipilih.

(Pranoto \& Octavian, 2015) melakukan kajian kualitatif tentang deskripsi pelaksanaan strategi di wilayah kepulauan Indonesia. Peneliti melakukan perencanaan strategi pengamanan Alur Laut Kepulauan Indonesia (ALKI) dengan pola choke point control. Perencanaan strategi ini menerapkan kemampuan pengawasan Kapal Republik Indonesia wilayah barat dengan pemanfaatn perkembangan teknologi dan peningkatan kerja sama dengan instansi lain.

\section{Teori Strategi}

Kata strategi berasal dari bahasa Yunani "strategos" yang memiliki arti seni para jenderal. Studi tentang strategi pada mulanya berkembang pada masa pasca perang dunia II atau saat awal perang dingin (Baylis, 2016). Di dalam dunia militer strategi umumnya digunakan untuk merencanakan bagaimana sebuah peperangan dapat dimenangkan. (Hart, 1991) mendefinisikan strategi sebagai suatu seni dari pendistribusian dan pengaplikasian alat atau cara-cara militer untuk memenuhi suatu kebijakan. Menurut pandangan Clausewitz, strategi diartikan sebagai penyusunan cara-cara bertempur agar kita dapat memperoleh tujuan. Clausewitz berfokus pada strategi perang, dimana dari strategi tersebutlah kemudian keluar pemenang perang. Clausewitz menilai bahwa strategi memiliki relasi yang begitu erat dengan politik dan perang, yang merupakan tujuan pembentukan strategi.

Strategi Clausewitz sangat direkomendasikan untuk pembelajaran dan penerapan kebijakan dapat dengan mudah terlaksana (Gray, 1999). Strategi seringkali diidentikkan dengan perang, namun menurut Liddel Hart teori ini melihat bahwa perang yang terjadi adalah untuk menciptakan perdamaian, menghindari terjadinya kerusakan, menciptakan keamanan, dan mencapai kesejahteraan. Oleh karena itu, tujuan strategi yang sebenarnya adalah tidak untuk mencari banyaknya 
pertempuran, akan tetapi untuk mencari situasi yang sangat menguntungkan bagi dirinya dalam mengambil keputusan. Pendekatan yang dirumuskan oleh Basil Liddell Hart disini adalah pendekatan tidak langsung, karena bahwa menyerang langsung musuh adalah pendekatan yang merugikan dan hampir tidak pernah membuahkan hasil (Hart, 1991). Pendekatan teori strategi ini dibagi menjadi empat, yakni: (1) Pendekatan Klasik; (2) Pendekatan Evolusioner; (3) Pendekatan Prosesual; (4) Pendekatan Sistemik (Whittington, 2001).

\section{Strategi Peperangan Kepulauan}

Peperangan kepulauan memiliki definisi yaitu penggunaan potensi kekuatan yang ada dengan jalan pertempuran yang dilaksanakan di wilayah dengan kondisi geografis kepulauan. Adapun konsep peperangan kepulauan mencakup strategi dan taktik peperangan laut yang dikembangkan sesuai dengan konfigurasi negara kepulauan. Pada hakikatnya strategi dan taktik yang diterapkan tetap mengacu pada ide dasar mawas keluar dan mawas kedalam seperti tertuang dalam konsep Strategi Pertahanan Laut Nusantara. Berdasarkan kondisi dan konstelasi geografis Indonesia dan aplikasi sinergitas antara kekuatan Pertahanan ranjau, Pertahanan laut, Pertahanan udara dan Pertahanan pantai, strategi perang laut secara simultan merupakan strategi dasar yang diterapkan pada medan peperangan kepulauan adalah sebagai berikut :

\section{a. Strategi Fleet in Being}

Strategi Fleet in Being adalah konsep penggunaan satuan angkatan laut untuk mengendalikan alur pelayaran tertentu dengan berusaha menghindari pertempuran. Strategi ini dilaksanakan oleh satuan-satuan laut kecil yang secara kuantitas dan kualitas tidak memiliki keunggulan dibandingkan dengan satuan musuh.

\section{b. Strategi Blockade}

Straegi Blockade adalah strategi pengepungan (containment atau sortie control) atau penutupan garis perhubungan laut untuk mencegah satuansatuan musuh memasuki laut terbuka dengan mengepung di pangkalan serta lawan pengendalian terhadap pertemuan alur-alur laut vital (choke point control).

\section{c. Strategi Decisive Battle (Pertempuran Menen-} tukan)

Decisive Battle atau Pertempuran yang menentukan merupakan pertempuran di laut yang menimbulkan kehancuran dan kekalahan musuh, sehingga menimbulkan dampak strategik terhadap jalannya perang. Decisive battle atau pertempuran yang menentukan pada prinsipnya dapat dilaku- kan oleh seluruh kekuatan angkatan laut baik yang besar maupun kecil bergantung kepada pengembangan taktik tempur yang ada dengan memanfaatkan segala aspek yang ada dalam peperangan laut seperti aspek pengelabuhan, aspek geografis mandala tempur dan lain sebagainya sehingga mampu mengalahkan atau menimbulkan kerugian musuh yang memberikan dampak secara luas terhadap strategi perang yang dilaksanakan oleh musuh.

\section{Konsep Decision Making Trial and Evaluation Laboratory (DEMATEL)}

Metode DEMATEL merupakan metode yang dikembangkan oleh Geneva Research Centre of the Battelle Memorial Institute (Fontela \& Gabus, 1973). Metode ini sangat berguna untuk menggambarkan struktur dari hubungan sebab akibat yang rumit dengan menggunakan matriks dan digraph (directed graph) atau Impact Relation Map (IRM). Matriks atau digraph menggambarkan hubungan antara komponen-komponen sistem dengan kekuatan hubungan antar komponen pada hubungan yang digambarkan tersebut secara kuantitatif (Sarkis, Fu, \& Zhu, 2010).

Tahapan DEMATEL adalah sebagai berikut:

Tahap 1: Membuat matriks keterkaitan secara langsung (A).

Tahap 2: Melakukan penormalan pada matriks keterkaitan secara langsung (M).

$$
k=\operatorname{Min}\left(\frac{1}{\max _{\mathbb{1} \leqslant \leqslant n} \sum_{j=1}^{n}\left|a_{i}\right|}, \frac{1}{\max _{\mathbb{1} \leqslant j \leqslant n} \sum_{i=1}^{n}\left|a_{i j}\right|}\right), \quad i, j=1,2,3, \ldots, n
$$

Tahap 3: Hitung matriks keterkaitan secara total (T).

$$
\begin{aligned}
S & =M+M^{2}+M^{2}+\ldots=\sum_{i=1}^{\infty} M^{i} \\
& =M(I-M)^{-1} \ldots \ldots \ldots \ldots \ldots \ldots \ldots \ldots \ldots \ldots \ldots \ldots
\end{aligned}
$$

Tahap 4: Tetapkan nilai ambang batas dan dapatkan Impact Relation Map (IRM) atau peta impact-digraph. Menghitung grup dispatcher dan grup receiver dengan menggunakan nilai $D-R$ dan $\mathrm{D}+\mathrm{R}$.

$$
\begin{aligned}
& S=\left[S_{i j}\right]_{n x n}, \mathrm{i}, \mathrm{j} \in\{1,2,3, \ldots, \mathrm{n}\} . \\
& D=\sum_{j=i}^{n} S_{i j} \\
& R=\sum_{i=1}^{n} S_{i j}
\end{aligned}
$$




\section{Konsep Analytic Network Process (ANP)}

Metode Analytic Network Process (ANP) merupakan pengembangan metode Analytical Hierarchy Process (AHP). Metode ANP mampu memperbaiki kelemahan AHP berupa kemampuan mengakomodasi keterkaitan antar kriteria atau alternatif (Saaty, Decision Making With Dependence and Feedback The Analytic Network Process (2nd ed.), 2001). Keterkaitan pada metode ANP ada 2 jenis yaitu keterkaitan dalam satu set elemen (inner dependence) dan keterkaitan antar elemen yang berbeda (outer dependence).

Tabel 1. Skala Perbandingan Berpasangan

\begin{tabular}{|c|l|}
\hline Tingkat Kepentingan & \multicolumn{1}{|c|}{ Definisi } \\
\hline 1 & Kedua elemen sama penting \\
\hline 3 & Satu elemen sedikit lebih penting daripada elemen yang lain. \\
\hline 5 & Satu elemen sesungguhnya lebih penting dari elemen yang lain. \\
\hline 7 & Satu elemen jelas lebih penting dari elemen yang lain. \\
\hline 9 & Satu elemen mutlak lebih penting daripada elemen lain. \\
\hline $2,4,6,8$ & Nilai tengah diantara 2 penilaian yang berdampingan. \\
\hline
\end{tabular}

\section{Prioritas Dalam Supermatrix}

Dalam penggabungannya dengan metode ANP, DEMATEL tidak hanya digunakan untuk mendeteksi hubungan antar kriteria dan membangun Impact- Relation Map (IRM), tetapi juga untuk mendapatkan tingkat pengaruh kriteria yang satu terhadap yang lain, selanjutnya menggunakannya sebagai dasar di dalam menormalisasi supermatriks untuk menentukan bobot dari ANP guna mendapatkan alternatif terbaik berdasarkan tingkat kepentingannya.

Tahap 5: Bandingkan kriteria-kriteria melalui pairwise comparisons sebagai dasar untuk membentuk Unweighted Supermatriks.

Tahap 6: Mendapatkan Weighted Supermatriks dengan cara mengalikan normalisasi matriks (T) hasil dari 4 langkah metode DEMATEL dengan Unweighted Supermatriks.

Tahap 7: Membuat perhitungan Limit terhadap Weighted Supermatriks $\left(\mathbf{W}_{\mathbf{w}}\right)$.

\section{Konsep dan Analisis BOCR (Benefit Op- portunity Cost and Risk)}

Untuk melakukan Analisa Benefits, Opportunities, Cost dan Risk sebagai analisa strategis, perhitungannya menggunakan metode Pairwise Comparasion. Secara struktural, sebuah keputusan dibagi menjadi tiga bagian, pertama sistem penilaian, kedua merits dari keputusan benefit cost opportunities dan risk (BOCR) sebagai pertimbangan membuat keputusan, dan ketiga hirarki atau jaringan keterkaitan, fakta (objektif) yang membuat sebuah alternatif keputusan lebih diinginkan dibanding yang lainnya (Saaty T. L., 2001). Hasil dari beberapa alternatif yang di prioritaskan, didapatkan tiga hasil : kondisi umum (standard Condition) B / C, Pessimistic B / (CxR) dan Realistic (BxO) / (CxR). Alternatif yang terbaik dipilih dengan nilai Realistic yang tinggi dan alternatif terpilih tersebut dipertimbangkan sebagai keputusan yang di tentukan dari alternatif lainnya (Wijnmalen, 2005).

\section{ANALISIS DAN PEMBAHASAN}

\section{Gambaran Objek Penelitian}

Pelaksanaan penerapan strategi Peperangan Kepulauan ini dilaksanakan di Perairan Ambalat yang dijadikan daerah pertempuran. Wilayah perairan ini dijadikan batasan penelitian sebagai model untuk pemilihan strategi TNI Angkatan Laut dalam Peperangan Kepulauan.

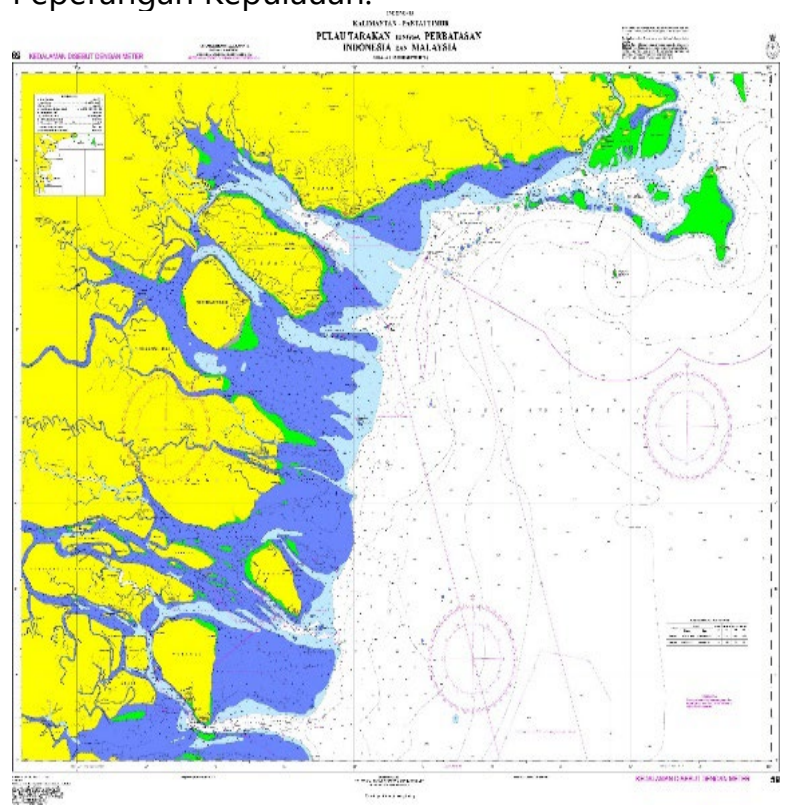

Gambar 1. Peta Perairan Ambalat

Ambalat terletak di Laut Sulawesi atau Selat Makassar, pada posisi 40 mil dari pulau Sebatik Indonesia atau 30 mil dari Pulau Bunyu, 12 mil dari Karang Unarang dan 12 mil selatan dari Pulau Sipadan Ligitan Malaysia (Asnawi, 2005). Sebagai ilustrasi bahwa luas yang harus dikontrol dan diamankan di perairan wilayah Ambalat adalah 10.750 $\mathrm{Km}^{2}$ dan wilayah Ambalat Timur 4.739,64 Km² yang secara keseluruhan kurang lebih $15.425 \mathrm{Km}^{2}$ (Rais, 2005). Ambalat berada di dekat perpanjangan perbatasan darat antara Sabah, Malaysia, dan Kalimantan Timur, Indonesia.

Kriteria-kriteria Penting yang Menentukan dalam Pemilihan Strategi Peperangan Kepulauan Berdasarkan kajian tentang peperangan Kepulauan dengan ditambahkan hasil wawancara dengan 
para expert serta studi literatur yang telah dilaksanakan, maka didapat kriteria dan subkriteria pemilihan strategi peperangan Kepulauan adalah:

\section{Kriteria Konstelasi Geografi}

Merupakan segala faktor geografi yang berhubungan dengan daerah perang dan memiliki pengaruh terhadap kapasitas penggunaan alutsista di medan perang yang akan menentukan penerapan strategi untuk menghadapi peperangan Kepulauan.

Tabel 2. Subkriteria Konstelasi Geografi

\begin{tabular}{|c|c|c|}
\hline No. & Subkriteria & Deskirpsi \\
\hline 1. & Arus Pasang Surut & $\begin{array}{l}\text { Tingkat kecepatan arus atas air dan bawah air, serta } \\
\text { kenaikan ketinggian permukaan air laut di daerah } \\
\text { pertempuran yang mempengaruhi olah gerak KRI. }\end{array}$ \\
\hline 2. & Angin & $\begin{array}{l}\text { Pengaruh kecepatan angin di dalam olah gerak kapal dan } \\
\text { kemampuan meluncur rudal kapal permukaan yang } \\
\text { dinyatakan dalam satuan knot. }\end{array}$ \\
\hline 3. & Suhu Udara & $\begin{array}{l}\text { Derajat panas dan dingin udara di atmosfer medan perang } \\
\text { yang dinyatakan dalam ukuran derajat Celcius. }\end{array}$ \\
\hline 4. & Tekanan Udara & $\begin{array}{l}\text { Tenaga yang bekerja untuk menggerakkan massa udara } \\
\text { setiap satuan luas tertentu yang diukur dengan } \\
\text { menggunakan barometer dan dinyatakan dalam satuan atm } \\
\text { (atmosfer). Tekanan udara dapat mempengaruhi keakuratan } \\
\text { roket yang ditembakkan dari darat ke laut atau udara. }\end{array}$ \\
\hline 5. & Sea State & $\begin{array}{l}\text { Merupakan kondisi umum dari permukaan laut dengan } \\
\text { memperhatikan tinggi gelombang dan kecepatan angin yang } \\
\text { memiliki pengaruh terhadap kemampuan operasi rancang } \\
\text { bangun kapal. Indikator yang menjadi acuan menggunakan } \\
\text { Beaufort Wind Force Scale. }\end{array}$ \\
\hline 6. & Kedalaman Laut & $\begin{array}{l}\text { Jarak yang diukur mulai dari permukaan sampai dengan } \\
\text { dasar laut menggunakan satuan } m \text { (meter). Kedalaman laut } \\
\text { memiliki pengaruh terhadap peralatan bawah air KRI seperti } \\
\text { echosounder dan sonar yang digunakan untuk identifikasi } \\
\text { sasaran bawah air. }\end{array}$ \\
\hline 7. & Dasar Laut & $\begin{array}{l}\text { Bentuk dasar laut daerah perang yang dijadikan sebagai } \\
\text { medan pertempuran yang memiliki pengaruh terhadap taktik } \\
\text { peperangan. }\end{array}$ \\
\hline 8. & Jarak antar Pulau & $\begin{array}{l}\text { Jarak yang menentukan kedekatan antar pulau dalam } \\
\text { penerapan taktik pertempuran di wilayah kepulauan. }\end{array}$ \\
\hline
\end{tabular}

\section{Kriteria Taktik Peperangan Kepulauan}

Merupakan doktrin taktik peperangan yang melibatkan berbagai peperangan dasar (principle warfare) yaitu peperangan permukaan (peperangan anti udara dan peperangan anti kapal permukaan ) dan peperangan bawah permukaan (peperangan ranjau dan peperangan anti kapal selam) serta peperangan khusus (peperangan elektronika).

Tabel 3. Subkriteria Taktik Peperangan Kepulauan

\begin{tabular}{|l|l|l|}
\hline \multicolumn{1}{|c|}{ No. } & \multicolumn{1}{|c|}{ Subkriteria } & \multicolumn{1}{|c|}{ Deskripsi } \\
\hline 1. & Mandala Operasi & $\begin{array}{l}\text { Daerah atau wahana laut yang diajdikan sebagai tempat } \\
\text { melakukan pertempuran peperangan kepulauan yang } \\
\text { dimanfaatkan menjadi taktik peperangan kepulauan. }\end{array}$ \\
\hline 2. & Disposisi Kesenjataan & $\begin{array}{l}\text { Pendisposisian kekuatan terhadap ancaman yang sudah } \\
\text { masuk ke wilayah pertahanan terakhir atau corong-corong } \\
\text { strategis yang tersebar sepanjang batas perairan } \\
\text { Indonesia. }\end{array}$ \\
\hline 3. & Pola Pengendalian & $\begin{array}{l}\text { Pengendalian kekuatan yang melaksanakan pertempuran } \\
\text { di peraian kepulauan dilaksanakan secara sinergi melalui } \\
\text { sarana C4 ISR (Coordination and Command, Control, } \\
\text { Comunication, Computer, Intelligence, Surveillance and } \\
\text { Reconnaissance). }\end{array}$ \\
\hline
\end{tabular}

\section{Kriteria Postur Kekuatan TNI Angkatan Laut}

Merupakan kondisi kemampuan dan kekuatan yang dimiliki oleh TNI Angkatan Laut di dalam menghadapi segala bentuk ancaman dengan segala bentuk perkembangaannya.
Tabel 4. Subkriteria Postur Kekuatan TNI AL

\begin{tabular}{|l|l|l|}
\hline No. & \multicolumn{1}{|c|}{ Subkriteria } & \multicolumn{1}{|c|}{ Deskripsi } \\
\hline 1. & Kesiapsiagaan & $\begin{array}{l}\text { Kemampuan Alutsista dan personil TNI } \\
\text { AL untuk mengantisipasi segala bentuk } \\
\text { ancaman yang kemungkinan terjadi. }\end{array}$ \\
\hline 2. & Kekuatan & $\begin{array}{l}\text { Kapasitas dan kualitas alutsista yang } \\
\text { dimiliki oleh TNI AL untuk melakukan } \\
\text { penghancuran atau mengatasi } \\
\text { ancaman. }\end{array}$ \\
\hline 3. & $\begin{array}{l}\text { Kemampuan } \\
\text { beroperasi yang } \\
\text { lama }\end{array}$ & $\begin{array}{l}\text { Alutsista yang dimiliki oleh TNI AL } \\
\text { dapat melakukan operasi sesuai } \\
\text { dengan kemampuan endurance } \\
\text { kehadiran di daerah operasi. }\end{array}$ \\
\hline
\end{tabular}

\section{Kriteria Kekuatan Negara Ancaman}

Merupakan faktor-faktor kemampuan tempur yang dimiliki oleh negara ancaman untuk melakukan agresi.

\section{Tabel 5. Subkriteria Kekuatan Negara Ancaman}

\begin{tabular}{|l|l|l|}
\hline No. & \multicolumn{1}{|c|}{ Subkriteria } & \multicolumn{1}{|c|}{ Deskripsi } \\
\hline 1. & Teknologi Alutsista & $\begin{array}{l}\text { Tingkat kemampuan sumber daya } \\
\text { modern militer yang dimiliki. }\end{array}$ \\
\hline 2. & $\begin{array}{l}\text { Gugus Tugas/Task } \\
\text { Force }\end{array}$ & $\begin{array}{l}\text { Satuan armada untuk melakukan } \\
\text { penyerangan terhadap armada lawan. } \\
\text { Kemampuan untuk menguasai seluruh } \\
\text { wilayah pertahanan udara di daerah } \\
\text { pertempuran. }\end{array}$ \\
\hline 3. & Air Superiority & $\begin{array}{l}\text { Kemampuan untuk mendapatkan data- } \\
\text { data dan segala informasi tentang } \\
\text { kekuatan negara lawan. }\end{array}$ \\
\hline 4. & Intelijen & \\
\hline
\end{tabular}

\section{Kriteria Peran Dawilhanla}

Merupakan pemberdayaan Potensi Maritim Nasional menjadi kekuatan pertahanan yang dipersiapkan secara dini meliputi wilayah pertahanan laut untuk melaksanakan Operasi Militer untuk Perang (OMP) yang pelaksanaannya didasarkan pada kepentingan pertahanan negara sesuai dengan Sistem Pertahanan Semesta.

\begin{tabular}{|c|c|c|}
\hline No. & Subkriteria & Deskripsi \\
\hline 1. & $\begin{array}{l}\text { Sumber Daya } \\
\text { Alam }\end{array}$ & $\begin{array}{l}\text { Potensi yang terkandung dalam bumi, } \\
\text { air, dan dirgantara yang dalam wujud } \\
\text { asalnya dapat didayagunakan untuk } \\
\text { kepentingan Pertahanan Negara. }\end{array}$ \\
\hline 2. & $\begin{array}{l}\text { Sumber } \\
\text { Manusia }\end{array}$ & $\begin{array}{l}\text { Seluruh Warga Negara Republik } \\
\text { Indonesia yang bertaqwa kepada } \\
\text { Tuhan Yang Maha Esa, setia kepada } \\
\text { Pancasila dan Undang-Undang Dasar } \\
\text { 1945, berumur } 18 \text { (delapan belas) } \\
\text { tahun sampai dengan } 45 \text { (empat puluh } \\
\text { lima) tahun, berkelakuan baik, sehat } \\
\text { rohani dan jasmani dan tidak dalam } \\
\text { keadaan kehilangan haknya untuk ikut } \\
\text { serta dalam usaha bela negara dapat } \\
\text { didayagunakan untuk kepentingan } \\
\text { Pertahanan Negara. }\end{array}$ \\
\hline 3. & $\begin{array}{l}\text { Sumber } \\
\text { Buatan }\end{array}$ & $\begin{array}{l}\text { Sumber Daya Alam yang telah } \\
\text { ditingkatkan dayagunanya } \\
\text { kepentingan Pertahanan Negara. }\end{array}$ \\
\hline 4. & $\begin{array}{l}\text { Sarana Prasarana } \\
\text { (Sarpras) }\end{array}$ & $\begin{array}{l}\text { Hasil budi daya manusia yang dapat } \\
\text { digunakan sebagai alat penunjang } \\
\text { untuk kepentingan Pertahanan Negara } \\
\text { dalam rangka mendukung kepentingan } \\
\text { nasional. }\end{array}$ \\
\hline
\end{tabular}


Nilai Keterkaitan Langsung Antar Kriteria dan Subkriteria

Nilai keterkaitan langsung antar kriteria dan subkriteria diperoleh dari kuesioner DEMATEL. Input data dalam kuesioner DEMATEL berupa angka yang menunjukkan keterkaitan antar kriteria dan subkriteria berdasarkan skala perbandingan DEMATEL.

Tabel 7. Matrik Rata-rata Nilai Keterkaitan Langsung Antar Kriteria

\begin{tabular}{|c|c|c|c|c|c|} 
& $\begin{array}{c}\text { Konstelasi } \\
\text { Geografi }\end{array}$ & $\begin{array}{c}\text { Taktik } \\
\text { Peperangan } \\
\text { Kepulauan }\end{array}$ & $\begin{array}{c}\text { Postur } \\
\text { Kekuatan } \\
\text { TNI AL }\end{array}$ & $\begin{array}{c}\text { Kekuatan } \\
\text { Negara } \\
\text { Ancaman }\end{array}$ & $\begin{array}{c}\text { Peran } \\
\text { Dawilhanla }\end{array}$ \\
\hline $\begin{array}{c}\text { Konstelasi } \\
\text { Geografi }\end{array}$ & 0,000 & 4,000 & 4,000 & 2,333 & 2,833 \\
\hline $\begin{array}{c}\text { Taktik } \\
\text { Peperangan } \\
\text { Kepulauan }\end{array}$ & 2,167 & 0,000 & 3,500 & 2,333 & 3,167 \\
\hline $\begin{array}{c}\text { Postur } \\
\text { Kekuatan } \\
\text { TNI AL }\end{array}$ & 4,000 & 4,000 & 0,000 & 3,667 & 3,667 \\
\hline $\begin{array}{c}\text { Kekuatan } \\
\text { Negara } \\
\text { Ancaman }\end{array}$ & 1,500 & 3,167 & 3,333 & 0,000 & 2,500 \\
\hline $\begin{array}{c}\text { Peran } \\
\text { Dawilhanla }\end{array}$ & 1,833 & 2,667 & 2,667 & 2,500 & 0,000 \\
\hline
\end{tabular}

\section{Hasil Perhitungan DEMATEL}

Data rata-rata nilai keterkaitan langsung antar kriteria dan subkriteria yang diperoleh dari hasil kuisioner akan diolah dengan persamaan-persamaan selanjutnya untuk mendapatkan hubungan saling keterkaitan antar kriteria dan subkriteria secara jelas berupa model terstruktur yang mudah dipahami. Berikut adalah hasil perhitungan selanjutnya yaitu matrik keterkaitan antar kriteria yang telah dinormalkan.

Tabel 8. Matrik Keterkaitan Antar Kriteria yang Telah Dinormalkan

\begin{tabular}{|c|c|c|c|c|c|}
\hline & $\begin{array}{c}\text { Konstelasi } \\
\text { Geografi }\end{array}$ & $\begin{array}{c}\text { Taktik } \\
\text { Peperangan } \\
\text { Kepulauan }\end{array}$ & $\begin{array}{c}\text { Postur } \\
\text { Kekuatan } \\
\text { TNI AL }\end{array}$ & $\begin{array}{c}\text { Kekuatan } \\
\text { Negara } \\
\text { Ancaman }\end{array}$ & $\begin{array}{c}\text { Peran } \\
\text { Dawilhanla }\end{array}$ \\
\hline $\begin{array}{c}\text { Konstelasi } \\
\text { Geografi }\end{array}$ & 0,000 & 0,289 & 0,289 & 0,169 & 0,205 \\
\hline $\begin{array}{c}\text { Taktik } \\
\text { Peperangan } \\
\text { Kepulauan }\end{array}$ & 0,157 & 0,000 & 0,253 & 0,169 & 0,229 \\
\hline $\begin{array}{c}\text { Postur } \\
\text { Kekuatan } \\
\text { TNI AL }\end{array}$ & 0,289 & 0,289 & 0,000 & 0,265 & 0,265 \\
\hline $\begin{array}{c}\text { Kekuatan } \\
\text { Negara } \\
\text { Ancaman }\end{array}$ & 0,108 & 0,229 & 0,241 & 0,000 & 0,181 \\
\hline $\begin{array}{c}\text { Peran } \\
\text { Dawilhanla }\end{array}$ & 0,133 & 0,193 & 0,193 & 0,181 & 0,000 \\
\hline
\end{tabular}

Setelah mendapatkan matrik keterkaitan secara langsung yang telah dinormalkan, maka matrik keterkaitan antar kriteria dan subkriteria secara total dapat diperoleh.
Tabel 9. Matrik Identitas - Matriks Normal (I-M)

\begin{tabular}{|c|c|c|c|c|c|}
\hline & $\begin{array}{c}\text { Konstelasi } \\
\text { Geografi }\end{array}$ & $\begin{array}{c}\text { Taktik } \\
\text { Peperangan } \\
\text { Kepulauan }\end{array}$ & $\begin{array}{c}\text { Postur } \\
\text { Kekuatan } \\
\text { TNI AL }\end{array}$ & $\begin{array}{c}\text { Kekuatan } \\
\text { Negara } \\
\text { Ancaman }\end{array}$ & $\begin{array}{c}\text { Peran } \\
\text { Dawilhanla }\end{array}$ \\
\hline $\begin{array}{c}\text { Konstelasi } \\
\text { Geografi }\end{array}$ & 1,000 & $-0,289$ & $-0,289$ & $-0,169$ & $-0,205$ \\
\hline $\begin{array}{c}\text { Taktik } \\
\text { Peperangan } \\
\text { Kepulauan }\end{array}$ & $-0,157$ & 1,000 & $-0,253$ & $-0,169$ & $-0,229$ \\
\hline $\begin{array}{c}\text { Postur } \\
\text { Kekuatan } \\
\text { TNI AL }\end{array}$ & $-0,289$ & $-0,289$ & 1,000 & $-0,265$ & $-0,265$ \\
\hline $\begin{array}{c}\text { Kekuatan } \\
\text { Negara } \\
\text { Ancaman }\end{array}$ & $-0,108$ & $-0,229$ & $-0,241$ & 1,000 & $-0,181$ \\
\hline $\begin{array}{c}\text { Peran } \\
\text { Dawilhanla }\end{array}$ & $-0,133$ & $-0,193$ & $-0,193$ & $-0,181$ & 1,000 \\
\hline
\end{tabular}

Tabel 10. Matrik (I-M) ${ }^{-1}$

\begin{tabular}{c|c|c|c|c|c|}
\hline & $\begin{array}{c}\text { Konstelasi } \\
\text { Geografi }\end{array}$ & $\begin{array}{c}\text { Taktik } \\
\text { Peperangan } \\
\text { Kepulauan }\end{array}$ & $\begin{array}{c}\text { Postur } \\
\text { Kekuatan } \\
\text { TNI AL }\end{array}$ & $\begin{array}{c}\text { Kekuatan } \\
\text { Negara } \\
\text { Ancaman }\end{array}$ & $\begin{array}{c}\text { Peran } \\
\text { Dawilhanla }\end{array}$ \\
\hline $\begin{array}{c}\text { Konstelasi } \\
\text { Geografi }\end{array}$ & 2,061 & 1,646 & 1,612 & 1,317 & 1,464 \\
\hline $\begin{array}{c}\text { Taktik } \\
\text { Peperangan } \\
\text { Kepulauan }\end{array}$ & 1,051 & 2,225 & 1,398 & 1,159 & 1,304 \\
\hline $\begin{array}{c}\text { Postur } \\
\text { Kekuatan } \\
\text { TNI AL }\end{array}$ & 1,400 & 1,804 & 2,544 & 1,513 & 1,647 \\
\hline $\begin{array}{c}\text { Kekuatan } \\
\text { Negara }\end{array}$ & 0,968 & 1,346 & 1,327 & 1,961 & 1,213 \\
Ancaman & 0,921 & 1,238 & 1,213 & 1,044 & 1,982 \\
\hline $\begin{array}{c}\text { Peran } \\
\text { Dawilhanla }\end{array}$ & 0.921 &
\end{tabular}

Tabel 11. Matrik M (I-M)-1

\begin{tabular}{c|c|c|c|c|c}
\hline & $\begin{array}{c}\text { Konstelasi } \\
\text { Geografi }\end{array}$ & $\begin{array}{c}\text { Taktik } \\
\text { Peperangan } \\
\text { Kepulauan }\end{array}$ & $\begin{array}{c}\text { Postur } \\
\text { Kekuatan } \\
\text { TNI AL }\end{array}$ & $\begin{array}{c}\text { Kekuatan } \\
\text { Negara } \\
\text { Ancaman }\end{array}$ & $\begin{array}{c}\text { Peran } \\
\text { Dawilhanla }\end{array}$ \\
\hline $\begin{array}{c}\text { Konstelasi } \\
\text { Geografi }\end{array}$ & 1,061 & 1,646 & 1,612 & 1,317 & 1,464 \\
\hline $\begin{array}{c}\text { Taktik } \\
\text { Peperangan } \\
\text { Kepulauan }\end{array}$ & 1,051 & 1,225 & 1,398 & 1,159 & 1,304 \\
\hline $\begin{array}{c}\text { Postur } \\
\text { Kekuatan } \\
\text { TNI AL }\end{array}$ & 1,400 & 1,804 & 1,544 & 1,513 & 1,647 \\
\hline $\begin{array}{c}\text { Kekuatan } \\
\text { Negara }\end{array}$ & 0,968 & 1,346 & 1,327 & 0,961 & 1,213 \\
Ancaman & 0,921 & 1,238 & 1,213 & 1,044 & 0,982 \\
\hline $\begin{array}{c}\text { Peran } \\
\text { Dawilhanla }\end{array}$ & 0 & & & \\
\hline
\end{tabular}

Berikut merupakan tabel yang menunjukkan matrik keterkaitan antar kriteria dan subkriteria secara total dengan menggunakan software Microsoft excel.

Tabel 12. Matrik Keterkaitan antar Kriteria Secara Total

\begin{tabular}{|c|c|c|c|c|c|c|c|c|}
\hline & KG & TPK & $\begin{array}{c}\text { PK TNI } \\
\text { AL }\end{array}$ & KNA & PD & D & D+R & D-R \\
\hline KG & 1,061 & 1,646 & 1,612 & 1,317 & 1,464 & 7,100 & 12,501 & 1,699 \\
\hline TPK & 1,051 & 1,225 & 1,398 & 1,159 & 1,304 & 6,137 & 13,396 & $-1,123$ \\
\hline $\begin{array}{c}\text { PK TNI } \\
\text { AL }\end{array}$ & 1,400 & 1,804 & 1,544 & 1,513 & 1,647 & 7,908 & 15,002 & 0,815 \\
\hline KNA & 0,968 & 1,346 & 1,327 & 0,961 & 1,213 & 5,815 & 11,809 & $-0,179$ \\
\hline PD & 0,921 & 1,238 & 1,213 & 1,044 & 0,982 & 5,398 & 12,009 & $-1,213$ \\
\hline R & 5,401 & 7,259 & 7,093 & 5,994 & 6,611 & & & \\
\hline
\end{tabular}


Nilai R adalah jumlah dari kolom yang merupakan besaran nilai suatu kriteria atau subkriteria dipengaruhi oleh kriteria atau subkriteria lainnya. Sedangkan $D$ adalah jumlah dari baris pada matrik keterkaitan secara total yang menunjukkan nilai seberapa besar kriteria atau subkriteria mempengaruhi kriteria atau subkriteria lainnya. Beberapa kriteria atau subkriteria dengan nilai D-R positif menunjukkan bahwa kriteria atau subkriteria tersebut mempunyai besaran nilai pengaruh (D) terhadap yang lainnya lebih besar dibandingkan dengan besaran nilai dipengaruhi $(R)$ oleh kriteria atau subkriteria lainnya, biasa disebut dispatcher. Sedangkan kriteria dengan nilai D-R negatif mempunyai nilai $D$ yang lebih kecil dibandingkan nilai $\mathrm{R}$ atau bisa dikatakan menerima pengaruh lebih besar dari kriteria yang lainnya, biasanya disebut receiver.

Tabel 13. Kriteria yang Termasuk Dispatcher dan Receiver

\begin{tabular}{|c|l|l|}
\hline No. & \multicolumn{1}{|c|}{ Dispatcher } & \multicolumn{1}{|c|}{ Receiver } \\
\hline 1. & Konstelasi Geografi & \\
\hline 2. & & Taktik Peperangan Kepulauan \\
\hline 3. & Postur Kekuatan TNI AL & \\
\hline 4. & & Kekuatan Negara Ancaman \\
\hline 5. & & Peran Dawilhanla \\
\hline
\end{tabular}

Tabel 14. Subkriteria yang Termasuk Dispatcher dan Receiver

\begin{tabular}{|c|l|l|}
\hline No. & \multicolumn{1}{|c|}{ Dispatcher } & \multicolumn{1}{|c|}{ Receiver } \\
\hline 1. & Arus Pasut & \\
\hline 2. & Angin & \\
\hline 3. & Suhu Udara & \\
\hline 4. & Tekanan Udara & \\
\hline 5. & Sea State & \\
\hline 6. & Kedalaman Laut & \\
\hline 7. & Dasar Laut & \\
\hline 8. & Jarak Antar Pulau & Mandala Operasi \\
\hline 9. & & Disposisi Kesenjataan \\
\hline 10. & & Pola Pengendalian \\
\hline 11. & & Kesiapsiagaan \\
\hline 12. & & Kekuatan \\
\hline 13. & & Kemampuan Ops. yang Lama \\
\hline 14. & & Teknologi Alutsista \\
\hline 15. & & Gugus Tugas \\
\hline 16. & & Air Superiority \\
\hline 17. & & Intelijen \\
\hline 18. & & \\
\hline 19. & Sumber Daya Alam & Sumber Daya Manusia \\
\hline 20. & & Sumber Daya Buatan \\
\hline 21. & & Sarana dan Prasarana \\
\hline 22. & & \\
\hline
\end{tabular}

Trheshold value untuk penelitian ini pada level kriteria adalah 1,294 sedangkan pada level subkriteria 0,20 sehingga tidak semua keterkaitan antar kriteria yang ada pada matrik keterkaitan antar kriteria maupun subkriteria secara total dapat dikonversikan pada peta impact-digraph. Berikut adalah peta impact-digraph yang merupakan hasil pengolahan DEMATEL yang akan dijadikan dasar dalam pembuatan model ANP berikutnya.

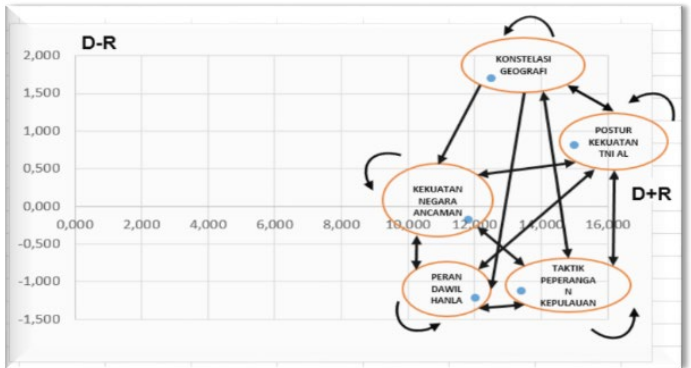

Gambar 2. Peta Impact-diagraph Pada Kriteria

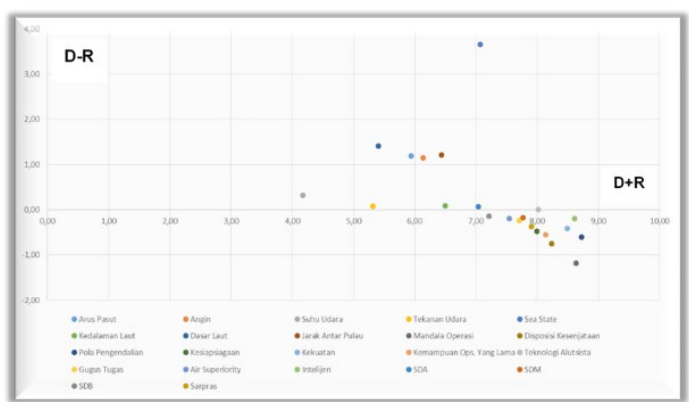

Gambar 3. Peta Impact-diagraph Pada Subkriteria

\section{Pembuatan Model Network ANP}

Setelah melakukan penghitungan dengan metode DEMATEL untuk mendapatkan hubungan antar kriteria dan subkriteria dan juga sebagai penentuan kapasitas sumber daya TNI AL yang digunakan dalam peperangan Kepulauan. Langkah selanjutnya adalah membuat model network ANP menggunakan software Super Decision berdasarkan peta impact-diagraph. Peta impact-digraph yang merupakan hasil pengolahan DEMATEL yang akan dijadikan dasar dalam pembuatan model ANP berikutnya di gambarkan pada Gambar 4.

\section{Hubungan Innerdependence dan Outerdepen- dence}

Digambarkan hubungan innerdependence dan outerdependence secara keseluruhan kluster dan elemen yang ada didalamnya sesuai dengan tanda panah yang telah digambarkan. Innerdependence

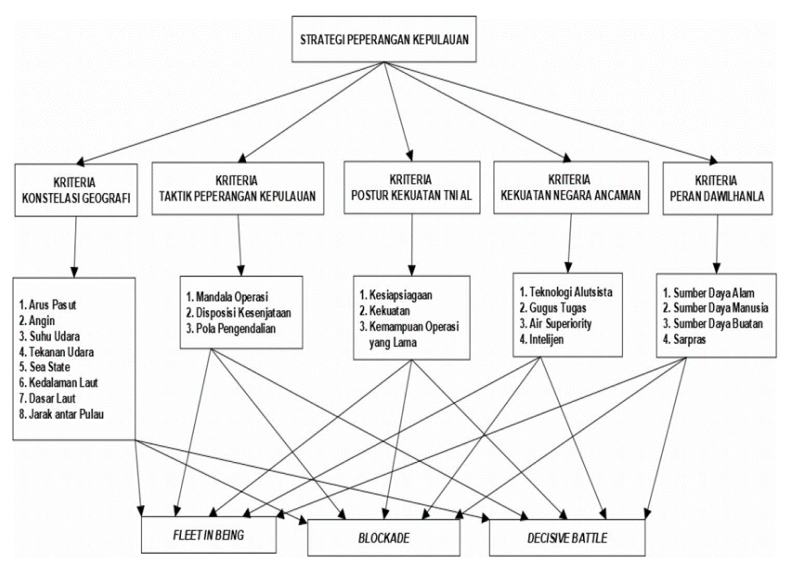

Gambar 4. Model ANP 


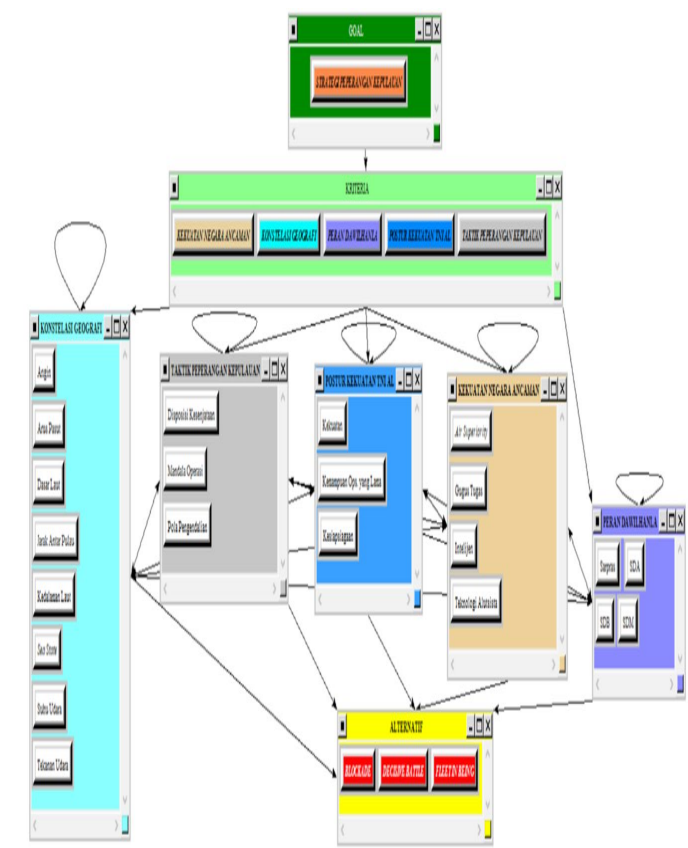

Gambar 5. Model Network ANP Menggunakan Super Decision

merupakan hubungan antar elemen dalam satu cluster, sedangkan koneksi antar elemen beda cluster disebut outerdependence. Sebagai contoh elemen (subkriteria) Sea State mempengaruhi elemen (subkriteria) Mandala Operasi. Sea State merupakan status permukaan laut di daerah perang yang akan mempengaruhi taktik peperangan kepulauan dalam hal ini Mandala Operasi untuk dapat melakukan perlawanan terhadap kekuatan armada lawan. Contoh lain yang memiliki hubungan innerdependence yaitu elemen (subkriteria) Disposisi Kesenjataan mempengaruhi elemen (subkriteria) Pola Pengendalian. Pengaruh ini memiliki arti bahwa Disposisi Kesenjataan di dalam Peperangan Kepulauan akan mempengaruhi Pola Pengendalian dari Taktik Peperangan yang dilakukan oleh unsur-unsur TNI AL di daerah perang. Berikut ini gambaran hubungan innerdependence dan outerdependence yang merupakan hasil dari pengolahan DEMATEL.

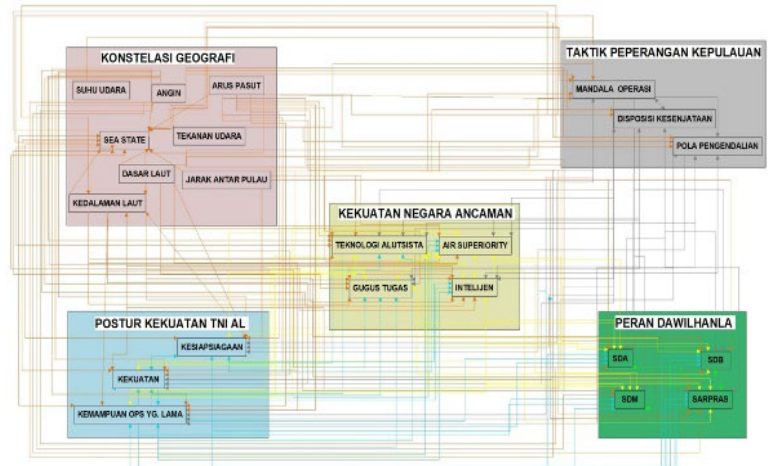

Gambar 6. Network ANP dengan Innerdependence dan Outerdependence
Perhitungan Nilai Bobot Prioritas Kriteria, Subkriteria dan Alternatif

Data yang telah diperoleh dari penyebaran kuisioner berupa nilai pairwise comparison antara kriteria, antar subkriteria dan antar alternatif pemilihan Strategi Peperangan Kepulauan. Selanjutnya rata-rata geometrik yang telah dihitung dimasukkan ke dalam matriks perbandingan berpasangan. Setelah didapatkan satu nilai pairwise comparison untuk masing-masing hubungan dilakukan perhitungan bobot prioritas lokal. Perhitungan ini bertujuan untuk mengetahui bobot masing-masing elemen yang saling berhubungan.

Tabel 15. Contoh Rekap Data Geomean Kriteria

\begin{tabular}{l|c|c|c|c|c|c|c|}
\hline & 1 & 2 & 3 & 4 & 5 & 6 & GEOMEAN \\
\hline Kekuatan Neg. Ancaman vs Konstelasi Geo. & 1,00 & 0,20 & 0,14 & 4,00 & 0,17 & 7,00 & 0,71 \\
\hline Kekuatan Neg. Ancaman vs Peran Dawilhanla & 0,50 & 3,00 & 0,20 & 0,33 & 6,00 & 7,00 & 1,27 \\
\hline Kekuatan Neg. Ancaman vs Postur Kekuatan TNI AL & 0,20 & 1,00 & 0,14 & 1,00 & 2,00 & 8,00 & 0,88 \\
\hline Kekuatan Neg. Ancaman vs Taktik Pep.Kepulauan & 0,20 & 0,13 & 5,00 & 3,00 & 4,00 & 0,25 & 0,85 \\
\hline Konstelasi Geo. Vs Peran Dawilhanla & 1,00 & 3,00 & 1,00 & 0,33 & 6,00 & 5,00 & 1,76 \\
\hline Konstelasi Geo. Vs Postur Kekuatan TNI AL. & 1,00 & 1,00 & 1,00 & 0,25 & 0,20 & 6,00 & 0,82 \\
\hline Konstelasi Geo. Vs Taktik Pep.Kepulauan & 1,00 & 0,20 & 0,33 & 0,25 & 2,00 & 0,25 & 0,45 \\
\hline Peran Dawilhanla vs Postur Kekuatan TNI AL & 0,20 & 0,17 & 0,20 & 1,00 & 0,17 & 0,14 & 0,23 \\
\hline Peran Dawilhanla vs Taktik Pep.Kepulauan & 0,20 & 0,13 & 0,20 & 3,00 & 0,17 & 0,14 & 0,27 \\
\hline Postur Kekuatan TNI AL vs Taktik Pep.Kepulauan & 1,00 & 0,14 & 3,00 & 1,00 & 0,50 & 1,00 & 0,77 \\
\hline
\end{tabular}

Setiap kali dilakukan pembobotan prioritas lokal yang harus diperhatikan adalah nilai konsistensinya, nilai inkonsistensinya tidak boleh melebihi nilai 0,1 . Sebagai contoh gambar di bawah ini adalah nilai inkonsistensi dari hasil perbandingan berpasangan antar kriteria adalah sebesar 0,0478. Nilai tersebut masih di bawah 0,1 yang berarti konsisten.

\begin{tabular}{|c|c|c|c|}
\hline $\begin{array}{l}\text { The inconsister } \\
\text { desirable to hay } \\
0.1\end{array}$ & $\begin{array}{l}\text { cy index is } 0.0478 \text {. It is } \\
\text { e a value of less than }\end{array}$ & & \\
\hline KEKUATAN NEGARA ANCAMAN & & 0.191790 & ( \\
\hline KONSTELASI GEOGRAFI & & 0.175188 & \\
\hline PERAN DAWILHANLA & & 0.115683 & \\
\hline POSTUR KEKUATAN TNI AL & & 0.213977 & \\
\hline $\begin{array}{l}\text { TAKTIK PEPERANGAN } \\
\text { KEPULAUAN }\end{array}$ & & 0.303362 & \\
\hline
\end{tabular}

Gambar 7. Inconsistency Index Antar Kriteria

\section{Penetapan Prioritas Pemilihan Strategi Peperan- gan Kepulauan}

Menurut hasil pengolahan data kuesioner ANP dengan menggunakan software super decisions diperoleh hubungan jejaring yang terjadi antar kriteria, antar subkriteria ataupun antar alterna- 
10 | Herdiawan, D. dkk. Penentuan Kriteria dan Strategi dalam Menghadapi Peperangan...

tif. Hasil perhitungan akhir berupa nilai ranking dari prioritas masing-masing alternatif strategi Peperangan Kepulauan. Melalui operasi synthesize, maka diperoleh hasil yang berisi antara lain nilai bobot alternatif.

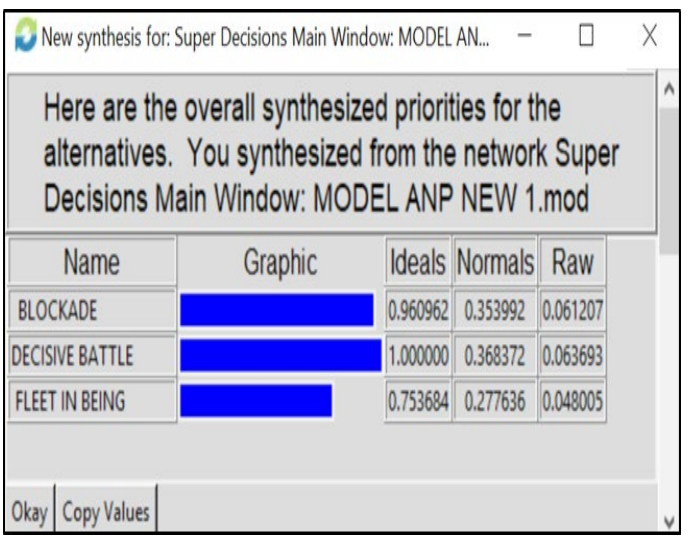

Gambar 8. Nilai Bobot Alternatif

Tahap selanjutnya adalah mengetahui prioritas secara keseluruhan dari kriteria dengan menjalankan Priorities pada Software Super Decisions sehingga didapatkan nilai bobot dari subkriteria. Kolom sebelah kanan dari Gambar di bawah ini merupakan nilai bobot yang dihasilkan dari Limiting Supermatriks pada pengolahan data ANP menggunakan software super decisions. Nilai tersebut merupakan bobot keseluruhan dari subkriteria-subkriteria yang telah ditetapkan. Sedangkan kolom sebelah kiri merupakan nilai bobot dari subkriteria-subkriteria yang telah dinormalisasi sesuai dengan kelompok cluster masing-masing.

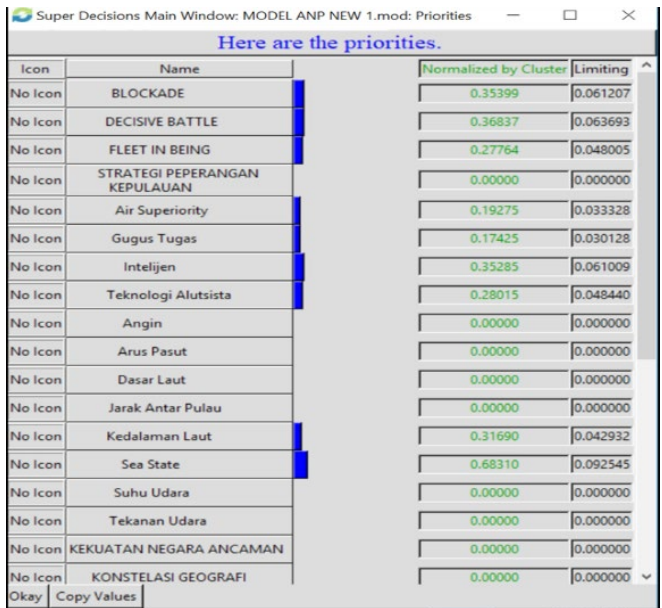

Gambar 9. Nilai Bobot Subkriteria

\section{Analisis Sensitivitas}

Pada tahap analisis sensitivitas ini dilakukan dengan menggunakan software super decisions yaitu dengan mengubah nilai bobot pada alternatif yang diuji. Melalui uji ini akan dapat diketahui bahwa dengan melakukan perubahan nilai bobot pada alternatif yang diuji akan mempengaruhi hasil perankingan semula atau tidak. Bilamana terjadi perubahan ranking atau prioritas, maka titik tersebut dinamakan dengan titik kritis suatu alternatif. Berikut ini contoh yang menunjukkan uji sensitivitas pada alternatif Decisive Battle.

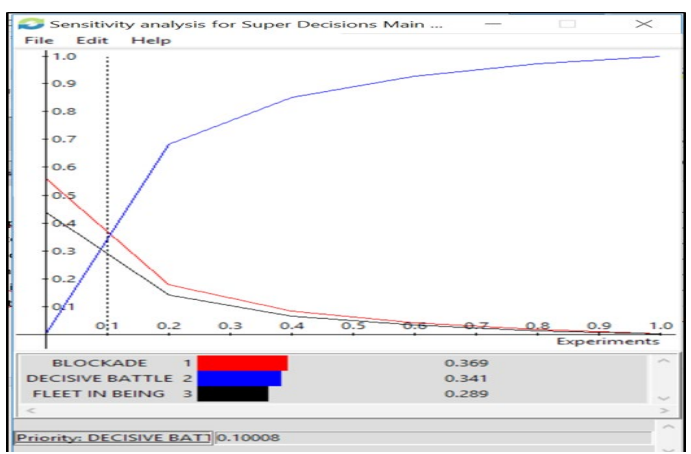

Gambar 10. Analisis Sensitivitas Alternatif Decisive Battle

Setelah dilakukan uji sensitivitas terhadap alternatif Decisive Battle menghasilkan nilai bobot kritis sebesar 0,10008.

Analisis sensitivitas selanjutnya adalah dengan mengubah nilai bobot pada subkriteria-subkriteria, sehingga dengan melakukan perubahan nilai bobot pada subkriteria tersebut akan mempengaruhi hasil perangkingan alternatif strategi Peperangan Kepulauan. Berikut ini merupakan analisis sensitivitas terhadap perubahan nilai bobot subkriteria yang berhubungan dengan perangkingan alternatif strategi Peperangan Kepulauan.

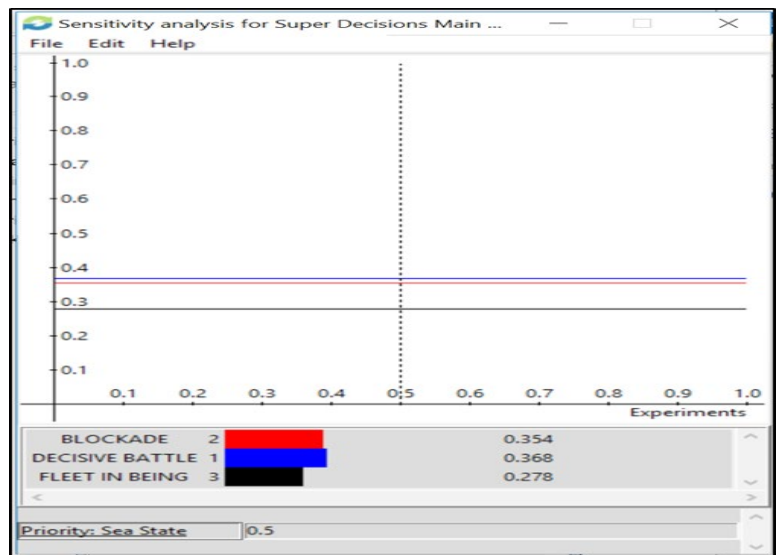

Gambar 11. Analisis Sensitivitas Perubahan Bobot Subkriteria

\section{Analisis BOCR (Benefit, Opportunity, Cost and Risk)}

Perumusan Kontrol Kriteria, Subkriteria dan Alternatif.

Berdasarkan model hirarki ANP yang telah dibuat pada subbab sebelumnya. Maka dilakukan proses pengelompokkan kriteria kontrol menjadi empat kriteria kontrol terhadap kriteria, subkriteria dan 
alternatif strategi TNI AL dalam Peperangan Kepulauan, yaitu keuntungan (Benefit), Potential Benefit (Opportunity), Biaya (Cost) dan Risiko (Risk).

Kontrol kriteria dalam hal ini adalah kriteria yang memberikan pengaruh signifikan sehubungan dengan tujuan untuk mencari alternatif strategi terbaik bagi TNI AL di dalam menghadapi Peperangan Kepulauan. Menurut Saaty, faktor-faktor yang menguntungkan dikelompokkan ke dalam faktor yang pasti menguntungkan (Benefit) dan faktor yang dapat menguntungkan dengan tingkat kepastian yang lebih rendah (Opportunity). Sementara itu, faktor-faktor yang tidak menguntungkan dikelompokkan ke dalam faktor yang pasti tidak menguntungkan (Cost) dan faktor yang dapat merugikan dengan tingkat kepastian yang lebih rendah (Risk) (Saaty T. L., 2001). Dari hasil eksplorasi dan keterangan dari expert atau narasumber, serta kajian untuk menentukan strategi terbaik TNI AL dalam menghadapi Peperangan Kepulauan, diperoleh daftar kontrol kriteria, kriteria, dan alternatif yang digambarkan ke dalam diagram hirarki.

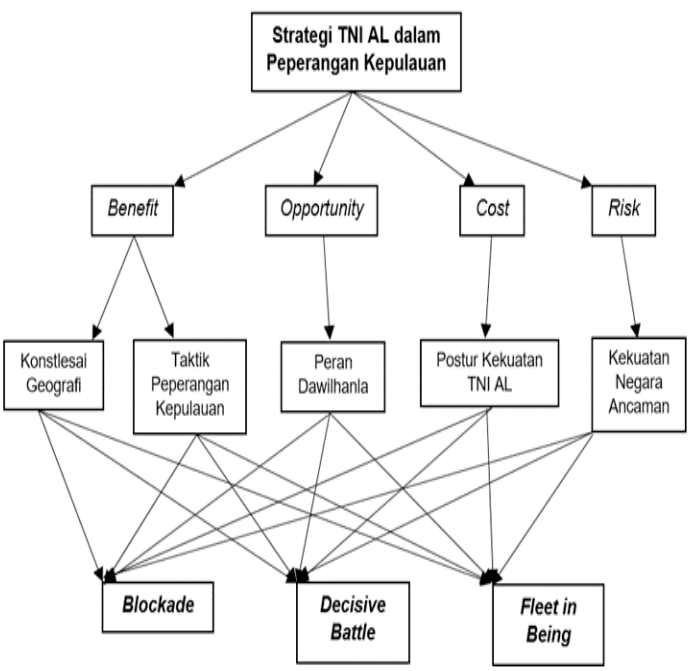

Gambar 12. Diagram Kontrol Kriteria

\section{Pembobotan BOCR}

Dari hasil pengolahan model hirarki ANP strategi Peperangan Kepulauan dengan menggunakan Software Super Decision melalui perbandingan berpasangan antar kriteria, subkriteria dan alternatif. Maka diperoleh bobot prioritas berdasarkan kelompok kontrol kriteria, kriteria dan alternatif.

Berdasarkan hasil dari bobot prioritas yang dilakukan melalui Pairwise Comparison di atas, diperoleh hasil untuk kontrol kriteria Benefit alternatif terpilih adalah Decisive Battle $(0,066179)$ dan prioritas subkriteria adalah Sea State $(0,197029)$. Kemudian untuk kontrol kriteria Opportunity alternatif terpilih

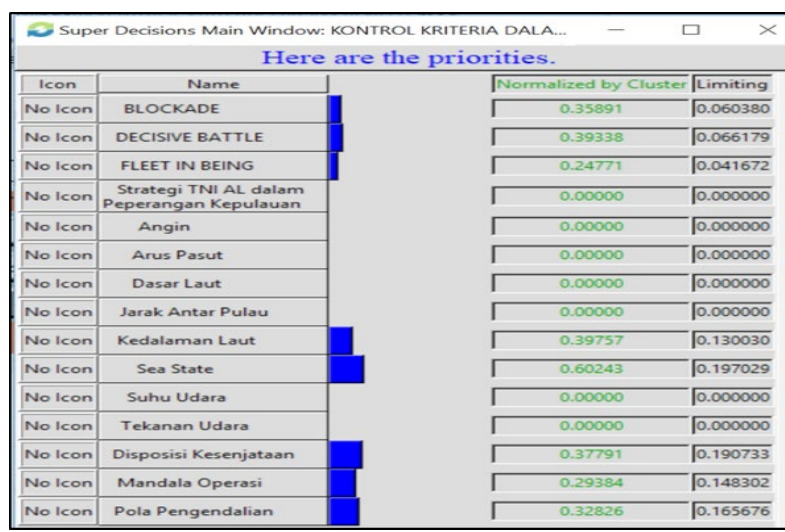

Gambar 13. Bobot Prioritas Kontrol Kriteria Benefit

\begin{tabular}{|c|c|c|c|}
\hline Esup & er Decisions Main Windo & IA DALA... & $\square$ \\
\hline & Her & rities. & \\
\hline Icon & Name & $\longdiv { \text { Normalized by Cluster } }$ & $=\sqrt{\text { er Limiting }}$ \\
\hline No Icon & BLOCKADE & 0.23436 & 0.156242 \\
\hline No Icon & DECISIVE BATTLE & 0.36605 & 0.244034 \\
\hline No Icon & FLEET IN BEING & 0.39959 & 0.266391 \\
\hline No Icon & $\begin{array}{c}\text { Strategi TNI AL dalam } \\
\text { Peperangan Kepulauan }\end{array}$ & 0.00000 & 0.000000 \\
\hline No Icon & Sarpras & 0.25403 & 0.084678 \\
\hline No Icon & SDA & 0.21095 & 0.070316 \\
\hline No Icon & SDB & 0.23566 & $\longdiv { 0 . 0 7 8 5 5 2 }$ \\
\hline No Icon & SDM & 0.29936 & 0.099787 \\
\hline
\end{tabular}

Gambar 14. Bobot Prioritas Kontrol Kriteria Opportunity

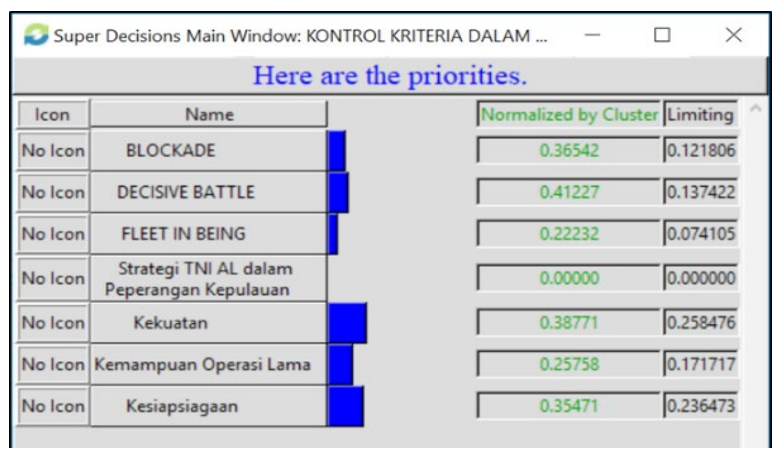

Gambar 15. Bobot Prioritas Kontrol Kriteria Cost

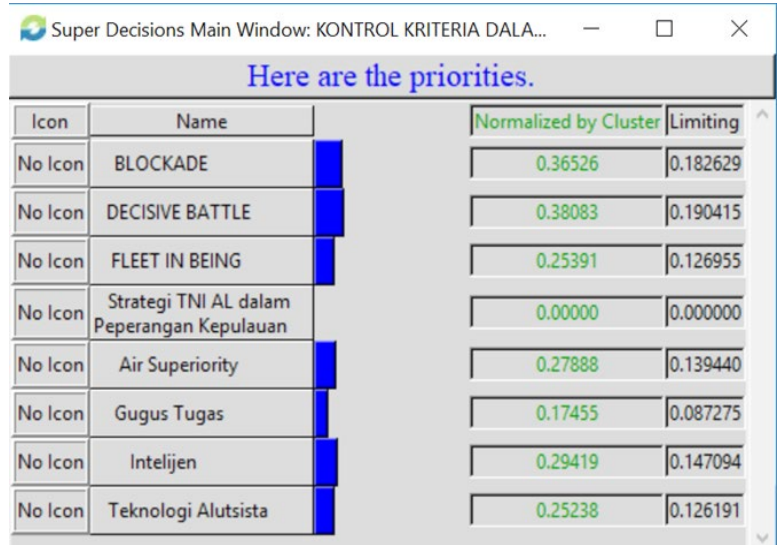

Gambar 16. Bobot Prioritas Kontrol Kriteria Risk 
adalah Fleet in Being $(0,266391)$ dan prioritas subkritteria adalah SDM $(0,099787)$. Untuk kontrol kriteria Cost pada strategi Peperangan Kepulauan ini adalah Decisive Battle $(0,137422)$ dan prioritas subkriteria adalah Kekuatan $(0,258476)$. Terakhir dari kontrol kriteria Risk alternatif terpilih adalah Decisive Battle $(0,190415)$ dan prioritas subkriteria adalah Intelijen $(0,147094)$.

Tabel 16. Analisis BOCR

\begin{tabular}{|cc|c|cc|c|c|c|}
\hline \multirow{2}{*}{ Alternatif } & Benefit & Opportunity & Cost & Risk & Standard & Pesimis & Realistis \\
\cline { 4 - 8 } & & & & & $B / C$ & $B /\left(C^{*} R\right)$ & $\left(B^{\prime} 0\right)\left(C^{*} R\right)$ \\
\hline BLOCKADE & 0,06038 & 0,156242 & 0,12180 & 0,18262 & 0,4957062 & 0,0905303 & 0,0141446 \\
\hline $\begin{array}{c}\text { DECISIVE } \\
\text { BATTLE }\end{array}$ & 0,06617 & 0,244034 & 0,13742 & 0,19041 & 0,4815750 & 0,0916991 & 0,0223776 \\
\hline $\begin{array}{c}\text { FLEET IN } \\
\text { BEING }\end{array}$ & 0,04167 & 0,266391 & 0,07410 & 0,12695 & 0,5623372 & 0,0713915 & 0,0190180 \\
\hline
\end{tabular}

Analisis di atas menggunakan 3 (tiga) skenario dalam analisis BOCR. Analisis yang pertama dengan menggunakan skenario standar yang hanya mempertimbangkan aspek Benefit dan Cost, diperoleh prioritas alternatif yaitu Fleet in Being dengan bobot 0,5623372. Pada skenario ini aspek Benefit lebih tinggi dibandingkan dengan aspek Cost, karena selaras dengan strategi Fleet in Being yang mengerahkan kekuatan Armada untuk standby di pangkalan terdekat daerah pertempuran tanpa adanya pergerakan kekuatan untuk melakukan serangan terhadap lawan.

Skenario yang kedua adalah dengan analisis pesimis yang mempertimbangkan aspek Risk selain aspek Benefit dan Cost dengan prioritas alternatif yaitu Decisive Battle dengan bobot 0,0916991. Pada skenario ini Decisive Battle memiliki aspek Risk terbaik selain aspek Benefit dan Cost yang menjadi pertimbangan dalam keputusan untuk melakukan penyerangan terhadapa kekuatan Armada Lawan.

Skenario terakhir merupakan skenario realitis yang memasukkan aspek Opportunity di dalamnya. Hasil analisis BOCR skenario ini diperoleh prioritas alternatif terbaik adalah Decisive Battle dengan bobot 0,0223776. Meskipun bobot Opportunity dari strategi Decisive Battle hanya prioritas kedua setelah alternatif strategi Fleet in Being.

\section{KESIMPULAN}

Berdasarkan hasil dari penelitian, pengolahan data, serta analisis dan interpretasi hasil pengolahan data yang telah dilakukan, maka kesimpulan yang dapat diambil dalam penelitian ini adalah:

a. Terdapat 5 (lima) kriteria utama di dalam pemilihan strategi TNI AL dalam menghadapi
Peperangan Kepulauan yaitu kriteria Konstelasi Geografi, Taktik Peperangan Kepulauan, Postur Kekuatan TNI AL, Kekuatan Negara Ancaman dan Peran Dawilhanla.

b. Hasil perhitungan metode DEMATEL, kriteria yang menjadi kelompok dispatcher adalah Konstelasi Geografi dan Postur Kekuatan TNI $\mathrm{AL}$, sedangkan yang menjadi kelompok receiver adalah Taktik Peperangan Kepulauan, Kekuatan Negara Ancaman dan Peran Dawilhanla.

c. Subkriteria yang mendapatkan bobot prioritas terbesar dalam pemilihan strategi TNI AL di dalam Peperangan Kepulauan pada masing-masing kriteria adalah:

1) Subkriteria Sea State dengan bobot prioritas 0,092545 (Kriteria Konstelasi Geografi).

2) Subkriteria Disposisi Kesenjataan dengan bobot prioritas 0,059647 (Kriteria Taktik Peperangan Kepulauan).

3) Subkriteria Kekuatan dengan bobot prioritas 0,075636 (Kriteria Postur Kekuatan TNI AL).

4) Subkriteria Intelijen dengan bobot prioritas 0,061009 (Kriteria Kekuatan Negara Ancaman).

5) Subkriteria Sarpras dengan bobot prioritas 0,057398 (Kriteria Peran Dawilhanla).

d. Urutan prioritas dari masing-masing alternatif strategi sebagai berikut:

1. Prioritas 1 adalah Strategi Decisive Battle dengan nilai bobot 0,06369 .

2. Prioritas 2 adalah Strategi Blockade dengan nilai bobot 0,06120 .

3. Prioritas 3 adalah Strategi Fleet in Being dengan nilai bobot 0,04800 .

e. Urutan prioritas terbaik masing-masing alternatif setelah dilakukan analisis BOCR:

1. Skenario Standar: Fleet in Being dengan bobot 0,562337224.

2. Skenario Pesimis: Decisive Battle dengan bobot 0,091699104.

3. Skenario Realistis: Decisive Battle dengan bobot 0,022377699.

\section{DAFTAR PUSTAKA}

Andrew F. Krepinevich, J. (2017). Archipelagic Defense The Japan-U.S. Alliance and Preserving Peace and Stability in The Western Pacific. Tokyo: The Sasakawa Peace Foundation.

Asnawi, S. (2005, Maret 16). Sinarharapan. Diambil kembali dari Sinarharapan.co.id: http://www. 
sinarharapan.co.id

Baylis, J. (2016). Strategy in The Contemporary World. Oxford: Oxford University Press.

Bintoro, Y. A. (2013). Aplikasi Metode DEMATEL dan ANP Pada Perbandingan CB (Cara Bertindak) Dalam Proses Perencanaan Operasi Amfibi. Surabaya: STTAL.

Chiu, Y. (2006). Marketing Strategy based on Customer behaviour for the LCD-TV . International Journal and Decision Making, 143-165.

Corps, U. M. (2017). Littoral Operations in a Contested Environment. Virginia: Departement of The Navy, United States of America.

Fontela, E., \& Gabus, A. (1973). DEMATEL, innovative methods, Technical report no. 2, Sructural analysis of the world problematique. Geneva: Battelle Geneva Research Isntitute.

Gray, C. S. (1999). "The Dimension of Strategy", in Modern Strategy. Oxford: Oxford University Press.

Hart, L. (1991). The Theory of Strategy . Dalam B.H., The Classic Book on Military Strategy (hal. 319333). London: Meridian Book.

Marsetio. (2013). Strategi TNI Angkatan Laut dalam Pengamanan Batas Maritim NKRI: Kajian Historis-Strategis. Jurnal Sejarah CITRA LEKHA, 1-18.

Plano, V. L., \& Creswell, J. W. (2008). The Mixed Methodes Reader. Nebraska: Sage.

Pranoto, H., \& Octavian, A. (2015). Security Strategy at Indonesia Archipelagic Sea Line. Jurnal Pertahanan, 93-108.

Purwoto, A. (2014, Oktober 5). Profesionalitas Prajurit TNI dalam Kerangka Minimum Essential Forces Guna Mendukung Kemandirian Pertahnan Negara. Jakarta: Kementerian Pertahanan.

Pushidrosal. (2017). Data Wilayah Negara Kesatuan Republik Indonesia. Jakarta: Mabesal.

Puspitasari, A., \& Ciptomulyono, U. (2011). Aplikasi Model Zero-One Goal Programming, DEMATEL, \& ANP Untuk Optimasi Pemilihan Strategi Pemasaran. Surabaya: Institut Teknologi Sepuluh Nopember.
Putri, S. N. (2017). Archipelagic State Responsibility On Armed Robbery at Sea. Indonesian Journal of International Law, 447-496.

Rais, A. R. (2005, Maret 7). Media Indonesia. Diambil kembali dari Media Indonesia.co.id: http:// www.mediaindonesia.co.id

Reeve, J. (2001). Maritime Strategy and Defence of The Archipelagic Inner Arc. Canberra: Royal Australian Navy.

S.Kusumadewi, S.Hartati, A.Harjoko, \& R.Wardoyo. (2006). Fuzzy Multi Atribut Decision Making (FUZZY MADM). Yogyakarta: Graha Ilmu.

Saaty, T. (2001). Decision Making With Dependence and Feedback The Analytic Network Process (2nd ed.). Pittsburgh, USA: RWS Publication.

Saaty, T., \& Vargas, L. (2006). Decision Making with the Analytic Network Process (Economic, Political, Social and Technological Applications with Benefits, Opportunities, Costs and Risk). New York: LLC.

Sadehnezhad, F., Zaranejad, M., \& Gheitani, A. (2013). Using Combinational Method DEMATEL and ANP with Fuzzy Approach to Evaluate Business Intelligence Performance. European Online Journal of Natural and Social Sciences, 1374-1386.

Sari, D. P., Pujotomo, D., \& Maryani, R. (2015). Penentuan Alokasi Pesanan Bahan Baku dengan Integrasi Metode Fuzzy TOPSIS dan Multi Choice Goal Programming di PT. Djarum Kudus. Jurnal SIMETRIS Universitas Diponegoro, Vol. 6 No.2.

Sari, P. R., Santoso, P. B., \& Hamdala, I. (2014). Pengambilan Keputusan Strategi Pemasaran Menggunakan Metode ANP dan Fuzzy TOPSIS (Studi Kasus: PT X Mojokerto). Jurnal Rekayasa dan Manajemen Sistem Industri, 428-437.

Sarkis, Fu, \& Zhu. (2010). A Grey-DEMATEL Methodology for Green Supplier Development Program Evaluation. Worcester: Clark University.

Seyed-Hosseini, S., Safaei, \& Asgharpour, M. (2005). Reprioritization of failure in a system failure mode and effects analysis by decision making trial and evaluation laboratory technique. Reliability Engineering and System Safety, 872-881. 
14 | Herdiawan, D. dkk. Penentuan Kriteria dan Strategi dalam Menghadapi Peperangan...

Shimizu, Y., \& Hori, S. (1999). Designing Methods of Human Interface For Supervisory Control Systems. Control Engineering Practice, 14131419.

Svensson, P. (1998). Archipelagic ASW-a Difficult Enterprise in Need of Holistic Approaches. International Conference on Multisource-Multisensor Information Fusion, 410-417.

Triantaphyllou, E. (1998). Multi-Criteria Decision Making: An Operations Research Approach. Encyclopedia of Electrical and Electronics Engineering, 175-186.

Tsai, W. H., \& Chou, W. C. (2009). Selecting Management Systems for Sustainable Development in SMEs: A Novel Hybrid Model Based On DEMATEL, ANP, and ZOGP. Experts Systems With Applications, 1444-1458.
Tzeng, G., C.H.Chiang, \& Li, C. (2007). Evaluating Intertwined Effects in e-learning Programs: A novel Hybrid MCDM model based on factor analysis and DEMATEL . Expert Systems with Applications, 1028-1044.

Vego, M. N. (2005). Naval Strategy and Operations in Narrow Seas. London: Frank Cass Publishers.

W.Wardhana. (2016). Poros Maritim: Dalam Kerangka Sejarah Maritim dan Ekonomi Pertahanan. Jurnal Masyarakat dan Budaya, 369-386.

Whittington, R. (2001). Theories of Strategy. London: Thompson.

Wu, W., \& Lee, Y. (2007). Developing global managers competencies using the fuzzy DEMATEL method. Expert Systems with Applications, 499-507. 